「計測自動制 御学 会論文集

Vol.53, No.2, 178/187 (2017)

\title{
作業者の運動情報を利用した作業進度の推定と それに基づく人協調ロボットのための作業支援スケジューリング
}

\author{
衣川潤*金 澤＼cjkstart亮*.小菅 一 弘* \\ Task Scheduling for Assembly Task Co-worker Robot \\ Based on Estimation of Work Progress Using Worker's Kinetic Information \\ Jun Kinugawa*, Akira Kanazawa* and Kazuhiro Kosuge*
}

\begin{abstract}
We have been developing a co-worker robot which works in cooperation with workers for an automobile assembly line. The co-worker robot is not directly involved in the assembly processes but carries out some nonessential tasks for supporting workers. In this paper, we improve our old system which decides a delivery timing based on logistic regression model. We propose a method to estimate a worker's current task for improving performance of timing decision system. To achieve these, the worker's behavior is modeled combining two probabilistic techniques: Gaussian mixture model for classifying areas corresponding to each task and hidden Markov model for modeling and recognizing a worker's action. By estimating a worker's behavior using a worker's kinetic information and supporting the worker at the proper timing, this system improves work efficiency and supplies the part to the worker effectively.
\end{abstract}

Key Words: co-worker robot, human robot collaboration, HMM, GMM, logistic regression model

\section{1.はじめに}

近年，産業用ロボットによる工場の自動化が進んでいるが， ロボットによる完全な自動化は未だ難しいというのが現状で ある，その理由として，近年主流となっている変種変量生産 方式への適用の難しさや，現在のロボット技術では実現が難 しい複雑な作業の存在, 1 台のロボットで複数の作業へ対応 するような汎用性の高いシステム構築の難しさが挙げられる. このような問題を解決するためのアプローチの 1 つとして, 人と協調して作業を行なうロボットシステムの研究開発が行 なわれるようになっている. Ronald らは, 組立工程におけ るロボット側のスケジューリングや制御を計算して協調作業 を行なうシステムを提案している ${ }^{1)}$. Nikolaidis らは, エン トロピーをもとにして計算されたマルコフ決定過程を利用し て, 作業者とロボットの作業モデルをベースとして協調作業 を行なうシステムを提案している ${ }^{2)}$. Mutluらは，近年の認 知科学の研究内容をもとにして，人とロボットが協働するた めの効率的なメカニズムの設計についてまとめている ${ }^{3)}$.

産業用ロボットによる自動化が最も盛んに進められている といわれている自動車産業においても, 車体に対する小さな部

* 東北大学大学院工学研究科 仙台市青葉区荒巻字青葉 6-6-01

* Graduated School of Engineering, Tohoku University, 6-601 Aramaki-Aoba, Aoba-ku, Sendai

(Received March 28, 2016)

(Revised November 4, 2016)
品の組付けやはめ込み作業など, 現在のロボット技術では実現 が難しく, 自動化の進んでいない工程が多数存在している.こ れらの現状に対する解決策として, 筆者らは作業者と協調して 作業を行なう「作業支援パートナロボット」を提案している. ロボットには難しい作業は人が行ない，人が行なう必要のな い作業はロボットが分担することで，作業効率の向上を図る. その 1 つが, 小型部品を扱う組立工程において作業支援を行 なう作業支援パートナロボット "PaDY (in-time Parts/tools Delivery to You robot)” 4)である. 筆者らは, PaDY のコン セプトを自動車の大型部品を扱う工程に適用させて，バンパ 組付工程で作業者にバンパを供給するロボットシステム“BPaDY" 5) 拈よび，ドア組付工程でドアの自動搬送と作業者の ドア組付支援を行なうロボットシステム“D-PaDY" 6)の研究 開発を行なっている.

ロボットと作業者による協調作業を考えた場合，作業者の 状況に応じてロボットが適切な行動を選択するような高度な 協調システムを実現することによって，作業支援システムの さらなる高効率化が期待される，従来研究においては，作業 者の移動軌道をマルコフモデルを利用してモデル化し, 部品 や工具の配送時間を予測することにより，作業者の作業待ち 時間を低減させる手法を提案している7)。この考え方をバン パ組付工程のような移動の少ない工程に対して適用し，作業 者の作業位置情報以外の情報も含めてロジスティック回帰モ デルを利用してモデル化を行ない，ロボットが作業支援を行 なうのに適切なタイミングを確率的に判断することで供給待 
ち時間の低減を図ってきた ${ }^{8)}$.しかし，移動の少ない工程を 対象とした従来研究 ${ }^{8)}$ においては作業内容を簡略化しており, 作業が複雑化する実際の工程にそのまま適用することは難し い. 作業者の作業位置情報以外の情報をうまく活用すること で, 複雑な作業フローに対しても適用可能な供給夕イミング 決定システムを構築する必要がある。

本稿では, 作業者の上半身の運動情報を利用することで, 移 動の少ない工程においても適用可能な作業進度推定手法を提 案する．作業者の運動情報を利用した作業進度推定アルゴリ ズムを従来のシステムに組み込み，従来提案してきた供給夕 イミング決定システムと統合する。ささらに，実際の工程を模 した環境で部品供給実験を行なって, 提案システムの有効性 を検証する．本論文の構成は以下のとおりである，まず，第 2 章では従来システムの課題とそれを解決するためのシステ ムの概要について説明する。第 3 章では，作業者の運動情報 を利用した作業進度推定手法の詳細について述べる。第 4 章 では, 作業者の状態にもとづいた供給タイミングの決定手法 の詳細について説明する。第 5 章では, 検証実験によって本 手法の有効性を検証し, 第 6 章を本稿の結言とする.

\section{2. 作業進度推定システムと供給タイミング決定システ 厶の概要}

\section{1 解決すべき課題}

従来システム ${ }^{8)}$ においては, 予定されているすべての作業 が終了してから，つぎの部品を受け取るまでの限定された場 面のみを想定している。しかし，実際の工程においてはさま ざまな作業が存在し，それらの作業が行なわれている間に供 給タイミング決定システムが誤判断を起こしてしまう。 そこ で, 作業者から得られる運動情報をもとに予定されている作 業の進度を推定し, 作業がすべて終了したと判断した後に従 来のシステムを利用して適切な供給夕イミングを決定する. これにより, 従来システムで実現していた適切なタイミング の決定システムを，より実際の工程に近い環境においても実 用可能なものとする.

移動が少ない工程において作業の進度を推定する際の難し さとして, 同じ位置で複数の作業が行なわれるという点が挙 げられる。そのため，作業者の移動の多い工程で利用してい た作業推定システム7)をそのまま適用することができない. そこで, 作業者の作業位置情報だけではなく，作業者の関節 位置の情報を考慮することで, 判別することのできる作業の 幅を広げる。これにより，細かく分けられた作業フロー中の 作業を判別し，各作業の開始をより正確に推定することが可 能となる。

\section{2 提案システムの構成}

本稿で提案するシステムの構成を Fig. 1 に示す. 本システ ムでは, Microsoft 社製の RGB-D センサ Kinect for Windows v2(以下 Kinect) を利用して，50 ms ごとに作業者の状 態を計測する.人間の 3 次元の関節位置や顔の向きなどの情 報をマーカレスで取得して, 統計モデルを利用して作業者の

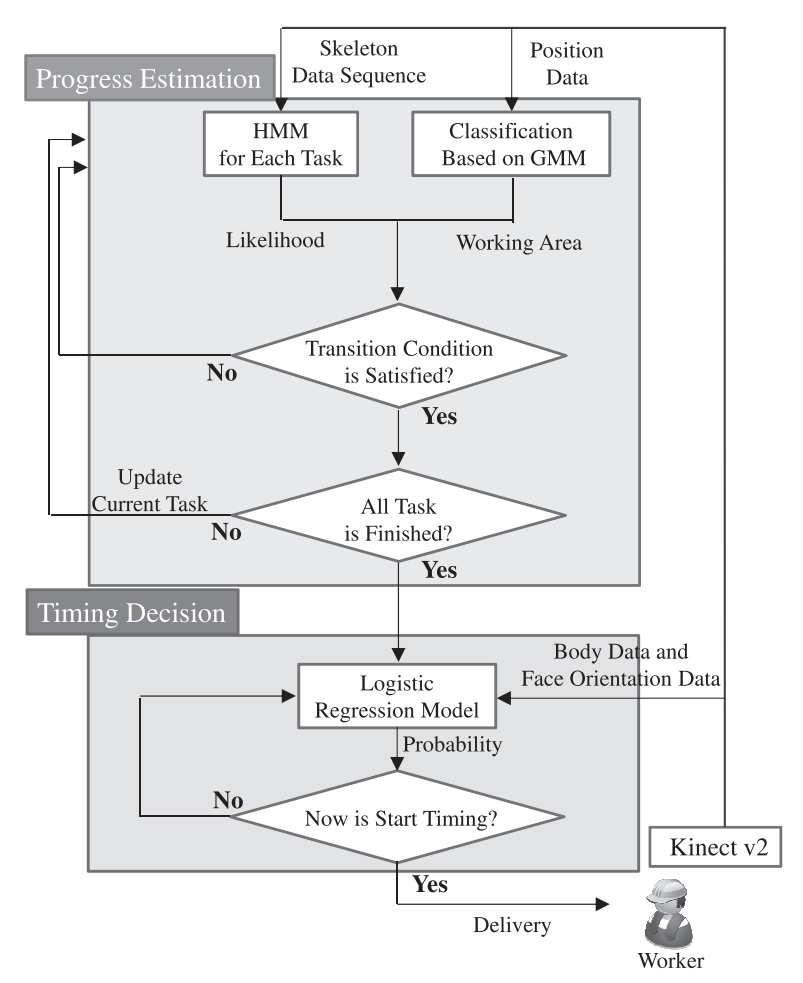

Fig. 1 System configuration

作業モデルを構築する，提案システムは，作業進度推定シス テムと供給タイミング決定システムの 2 つに大別される。ま ず事前に構築しておいた作業モデルにもとづいて，作業者の 現在の作業内容を判別する。これをすべての作業が終了した と判断されるまで繰り返し行なう。すべての作業が終了した と判断された後に, センサから得られる作業者の状態にもと づいて, 現在が供給タイミングとして適切かどうかを確率的 に判断する。

作業進度推定システムについては, 従来研究で行なってい た作業者の作業位置情報を利用した作業内容推定手法に, 関節 位置情報を利用した作業内容推定手法を組み合わせる。これ により, バンパ組付工程のような移動の少ない工程に対応で きるシステムへと拡張する. 自動車組立工程には各工程に対 して工程表が存在しており，現在の作業に対してつぎに行な う作業があらかじめ決められている。この自動車組立工程特 有の性質を利用して, 作業者の作業位置情報と作業者の関節 位置情報の時系列データから作業モデルを構築し, 作業者の 行なっている作業の遷移を推定する。まず混合ガウスモデル (Gaussian Mixture Model, 以下 GMM) を利用して, 作業者 の作業位置情報のクラスタリングを行ない, 作業者の大まかな 作業領域を決定する。さらに，隠れマルコフモデル (Hidden Markov Model, 以下 HMM) を利用して, 作業者の関節位置 の情報をもとにして作業者の行動認識を行ない, 対象とする 作業が行なわれている尤度を計算する。これら 2 つの情報を 組み合わせることで，作業の遷移を推定する.

作業進度推定システムによってすべての作業が終了したと 判断されたら, 供給タイミング決定システムによって適切と考 


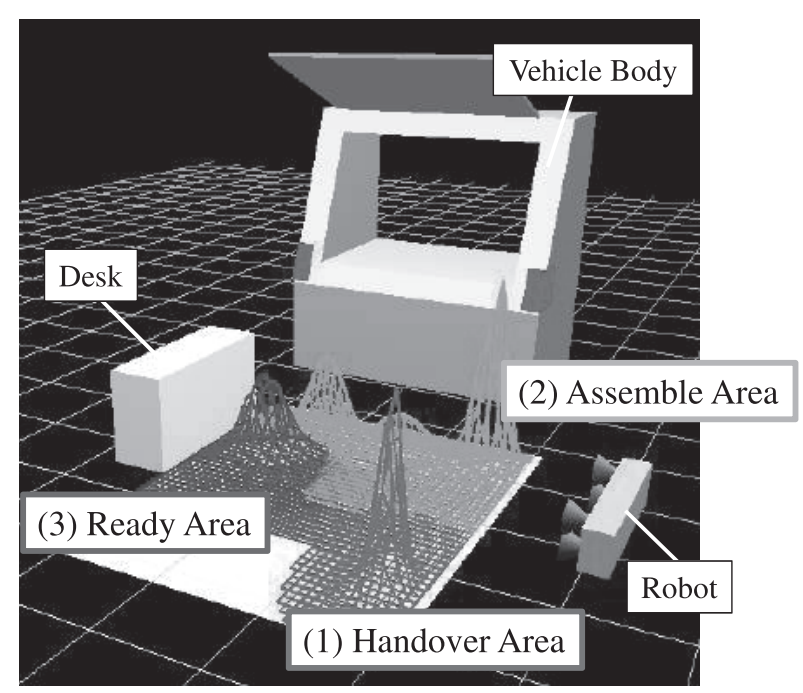

Fig. 2 Example of GMM in the work space

えられる供給タイミングが決定される，作業者の重心位置，体 の向き, 顔の向きといった複数の情報を利用してロジスティッ ク回帰モデルを構築し，その瞬間が供給タイミングとして適 しているかどうかを確率的に判断する．その瞬間が供給夕イ ミングとして適切であると判断されると，ロボットから作業 者へと部品の供給が行なわれる．各手法の詳細については次 章以降で説明する.

\section{3. 作業進度の推定}

\section{1 作業位置情報を利用した大まかな作業領域の判別} 作業位置情報から作業領域を大まかに判別するために, 従来 手法である GMM ベースのクラスタリングを利用する．本稿 ではバンパ組付工程を対象とし, (1) Handover Area, (2) Assemble Area, (3) Ready Area の 3 つの領域の判別を行な う. (1) Handover Area は作業者がロボットから部品を受け 取る領域を指す。(2) Assemble Area は部品を車体に組付け る作業全般を行なう領域を指す。(3) Ready Area は電動工 具やボルトの置かれた作業机周辺の領域を指す.

実際に組付け作業を行なっている際の作業者の 2 次元位置 データを学習データとして, 2 次元の GMM によって各作業 領域をモデル化する．GMM は混合ガウス分布を利用したモ デルであり，複雑な分布を単純なガウス分布の組み合わせと して表現することができる．混合ガウス分布は以下の式で表 わされる。

$$
p(\boldsymbol{x})=\sum_{m=1}^{M} \pi_{m} N\left(\boldsymbol{x} \mid \boldsymbol{\mu}_{m}, \Sigma_{m}\right)
$$

ここで， $M$ は正規分布の混合数， $\pi$ は混合係数， $\boldsymbol{\mu}$ は平均べ クトル， $\Sigma$ は共分散行列である. 各パラメータは EM アルゴ リズムによって学習される ${ }^{9)}$. 混合数 $M$ については BIC を もとにして決定する ${ }^{10)}$. BIC が小さいほどより良いモデル であるという考え方のもとで，判別に用いる混合ガウス分布 の混合数を決定する. Fig. 2 に今回対象とした作業領域の 3
次元モデルと作成した GMM の一例を示す．各分布の色が， その位置において属している確率が最も高いと考えられる領 域を表わしている。

実際の作業判別には，作成した GMM に属するガウス分布 をクラスタと置き換えて，計測した未知データに対してクラ スタリングを行なうことによって判別を行なう。ベイズの定 理の考え方を利用することにより，計測された未知データが GMM の各クラスタに属する確率は以下のように計算される.

$$
p\left(Y=m \mid \boldsymbol{x}_{n}\right)=\frac{N\left(\boldsymbol{x}_{n} \mid \boldsymbol{\mu}_{m}, \boldsymbol{\Sigma}_{m}\right)}{\sum_{m=1}^{M} \pi_{m} N\left(\boldsymbol{x}_{n} \mid \boldsymbol{\mu}_{m}, \boldsymbol{\Sigma}_{m}\right)} \pi_{m}
$$

ここで, $p\left(Y=m \mid \boldsymbol{x}_{n}\right)$ は観測データ $\boldsymbol{x}$ が $m$ 番目のクラス夕 に属する確率であり，ベイズの定理においては事後確率に相 当する．混合係数 $\pi_{m}$ はベイズの定理における事前確率に相 当する. $N\left(\boldsymbol{x}_{n} \mid \boldsymbol{\mu}_{m}, \boldsymbol{\Sigma}_{m}\right)$ はべイズの定理における尤度関数 に相当し，右辺の分母にあたる混合ガウス分布によって正規 化される. $p\left(Y=m \mid \boldsymbol{x}_{n}\right)$ が最大となるクラス夕を選ぶこと によって，作業位置の判別が行なわれる.

しかしながら，(2) Assemble Area については同一の場所 で複数の作業が行なわれるため，作業位置情報を利用した作業 内容の判別のみでは不十分である。そこで，次節で説明する 関節位置を利用した作業内容推定を組み合わせることによっ て，より細かい作業内容の推定を行なう。

\section{2 関節位置情報を利用した作業進度推定}

前節で説明した作業者の作業位置情報を利用した作業内容 推定のみでは，すべての作業を判別することはできない。こ れらの作業を判別するために，作業者の体の動きをモデル化 して行動認識を行なう。人間の行動認識は，特にコンピュー タビジョンや画像処理の分野で広く研究が行なわれており, 動画解析やロボティクス，人と電子機器がかかわるさまざま なシステムに適用されている。近年では，七ンサの性能の向 上や人物追跡手法の発展によって, 3 次元の関節位置情報を 利用した人間の行動認識の研究が行なわれるようになった。 Uddin らは，RGB-D センサから取得する人間の各関節の角 度情報を利用して，HMM によって人間の行動をモデル化し て行動認識を行なっている ${ }^{11)}$. Xia らは，RGB-D センサと して Kinectを利用し，各関節位置の情報から位置の不確実 性を考慮したヒストグラムを作成して行動認識を行なってい $ろ^{12)}$.これらの 3 次元の関節位置情報を利用した手法は，ど ちらについても非常に高い精度で人間の行動認識を行なって いる.

HMM は時系列パターンの解析やモデル化によく用いられ る手法であり，時間軸方向の伸縮への強さや複数の学習デー 夕からモデル構築が可能であるといった特徵がある，人間の 動作のような不確実な時系列パターンを確率的に判別できる ことから，本システムに抏いも HMM をべースとした行 動認識手法を利用する。一般的な HMM の定義式を以下に示 す13).

$$
\lambda=(\Pi, A, b)
$$


ここで, П は初期状態確率, $A$ は状態遷移確率行列, $b$ は各 状態における観測時系列の出力確率であり, この 3 つのパラ メータによって HMM は構成される。これらのパラメータは Baum-Welch アルゴリズムを用いて学習させる ${ }^{13)}$. 本シス テムにおいては，対象とする作業内容がほとんど上半身の動 きのみで行なわれることを考慮して，作業者の左右肘，左右 手の 3 次元位置のデータを利用し, 合計 12 次元の変数を観 測データとする.

行動認識の分野においては, Left-to-right 型の HMM によ る時系列データのモデル化が有効であることが知られている. Left-to-right 型の HMM は状態が左から右へと一方向に遷移 するため, 時間の経過と共に進行する現象のモデル化に適し ている。また，本手法では連続確率分布 HMM を利用する. これにより，コードブックの作成や量子化誤差の影響を考慮 する必要がなくなる．連続確率分布 HMM の出力確率の決定 に利用する確率密度関数にはさまざまな分布が考えられるが， 本手法では一般的に用いられることの多いガウス分布を採用 した.すなわち, 各状態 $i$ における出力確率 $b_{i}$ は以下のよう になる。

$$
b_{i}(t)=\frac{\exp \left(-\frac{1}{2}\left(\boldsymbol{o}(t)-\boldsymbol{\mu}_{i}\right)^{\mathrm{T}} \Sigma_{i}^{-1}\left(\boldsymbol{o}(t)-\boldsymbol{\mu}_{i}\right)\right)}{(2 \pi)^{\frac{D}{2}} \sqrt{\left|\Sigma_{i}\right|}}
$$

ここで, $\boldsymbol{o}(t)$ は時刻 $t$ における観測データ, $D$ は観測デー夕 変数の次元であり, 今回は $D=12$ となる. $\boldsymbol{\mu}_{i}, \Sigma_{i}$ はそれ ぞれ状態 $i$ における出力確率の平均べクトルと共分散行列で ある．作成した各モデルの尤度は，Forward Algorithmを用 いて以下の手順で計算する。

\section{Initialization:}

$$
\alpha_{i}(1)=\pi_{i} b_{i}(1), \quad 1 \leq i \leq N
$$

\section{Induction:}

$$
\begin{array}{r}
\alpha_{j}(t+1)=\sum_{i=1}^{N} \alpha_{i}(t) a_{i j} b_{j}(t+1) \\
1 \leq t \leq T-1, \quad 1 \leq j \leq N
\end{array}
$$

\section{Termination:}

$$
P(O \mid \lambda)=\sum_{i=1}^{N} \alpha_{i}(T)
$$

ここで， $O$ はセンサが観測する時系列データ， $T$ は観測時系 列の長さ, $N$ は HMM の状態数である. $\alpha_{i}(t)$ は, 時刻 $t$ に おいて状態 $i$ に存在する確率を表わしている. (7) 式で計算 された尤度 $P(O \mid \lambda)$ が閾值を超えたときに作業が遷移したと 判断する.

\section{4. 供給タイミングの決定}

\section{1 モデルパラメータ候補の定義}

人間とロボットの間で行なわれる物体の受け渡しについて の研究は数多く行なわれている. Strabala らは, 物体受け渡 しのプロセスを搬送，合図，手元化の 3 つに分け，まず人間
同士の物体受け渡し動作を解析し，その結果から得られた望 ましい受け渡しタイミングやロボットの姿勢, 物体の近づけ 方をロボットと人間による物体の受け渡し作業へと適用させ ている ${ }^{14)}$. Basili らは，人間同士の受け渡しの中の，実際に 受け渡しを行なう場面 (transfer part) に注目して，受け渡 しの距離や速度といった数值的な部分から解析を行なってい る ${ }^{15)}$. Cakmak らは，ロボットが物体の受け渡しを開始す る際のアームの姿勢の変化に着目し, 受け渡しの際にロボッ トの姿勢の曖昧さが及ぼす影響を考察し, 受け渡しの際の口 ボットの姿勢の設計方法についてまとめている ${ }^{16)}$ 。これらを 始めとした物体受け渡しに関する研究の中で, 物体の受け渡 しタイミングの決定に用いられている情報として以下が挙げ られる。
a)作業者の視線
b) 作業者の体の向き
c）作業者とロボット (エンドエフェクタ)の相対位置
d) 経過時間
e) ロボットが物体をもつ姿勢
f）作業者からのアクション

これらの情報から適切な供給タイミングを決定する手法を考 える，上記の情報のうち，d）については，作業者ごとの作業 時間のばらつきが大きすぎたため使用しないこととした，e) については，どの姿勢が物体を受け渡す姿勢として適してい るかを事前に検討しておく必要があるため, 本稿で提案する 手法においては使用しないこととした。また，f）は作業者の 意図を最も推定しやすい非常に重要な情報であるが，作業者 の作業を増やしてしまうのを避けるために本手法では使用し ないこととした。最終的に，本手法で使用する情報として選 択したのは, a) 作業者の視線，b) 作業者の体の向き, c) 作業 者とロボット (エンドエフェクタ)の相対位置の 3 つである. これら 3 つの情報は, どれもセンサによって数值としてデー 夕を取得することが可能な情報である．本手法で検討する変 数をまとめると以下のとおりである.

- 作業者の重心位置 $\left(M_{x}, M_{y}\right)$

- 作業者の重心速度 $\left(V_{x}, V_{y}\right)$

・作業者の体の向き $\left(O_{x}, O_{y}, O_{z}\right)$

-作業者の顔の向き $\left(F_{x}, F_{y}, F_{z}\right)$

\section{2 ロジスティック回帰モデル}

本研究では, ロジスティック回帰モデルを使用して, バン パ受け渡し時のロボットの「判断」を統計モデル化する ${ }^{17)}$. ロジスティック回帰モデルは疫学研究などの分野で幅広く利 用されているモデルであり，「起きる」か「起きない」かの 2 值で表現される事象について, 多值の連続变数を用いてその 生起確率をモデル化するため, 判断のモデル化に適した数理 モデルであると考えられる.

判断のモデル化については，ニューラルネットワークを利 用した手法 ${ }^{18)}$,19)や，サポートベクターマシンを利用した方 法 ${ }^{20)}$,21) など考えられる. しかし今回対象とする供給夕イ ミングの判断については, モデル化の際に有意になる変数とそ 
うでない変数が明確であると予想されるため，ロジスティッ ク回帰モデルと AIC を利用した統計分析にもとづいて必要な 変数の選択を行ない，モデルが学習デー夕に過剩に適合する ことを回避し, 汎化性能の高い識別モデルの構築を行なう.

ある現象の生起を説明するために観測された説明変数群を $\boldsymbol{x}=\left(x_{1}, \cdots, x_{r}\right)$ とし, その生起の結果を従属変数 $y$ で表わ すとする.ここで $y=1$ のときはある事象が生起したとし, $y=0$ のときは生起しなかったとする．ロジスティック回㷌 モデルに使用するサンプルデータは，サンプルの数を $N$ とし て, $n$ 番目のサンプル $(n=1, \cdots, N)$ に関して以下のよj に定義される。

$$
\left(y_{n}, x_{1 n}, \cdots, x_{r n}\right)
$$

$\boldsymbol{x}=\left(x_{1}, \cdots, x_{r}\right)$ という状態のもとで現象が発生するとい う条件付き確率 $p(y=1 \mid \boldsymbol{x})$ をロジスティック関数を用いて 表現したモデルをロジスティック回帰モデルという．ロジス ティック関数の式を以下に示す.

$$
p(y=1 \mid \boldsymbol{x})=\frac{\exp (Z)}{1+\exp (Z)}
$$

ここで, $Z$ は $r$ 個の変数の影響を表わす線形な重回帰式であ り, 次式で与えられるとする。

$$
Z=\beta_{0}+\beta_{1} x_{1}+\cdots+\beta_{r} x_{r}
$$

ここで， $\beta_{i}$ は $i$ 番目の説明変数の偏回帰係数である．ロジス ティック回帰モデルの構築には最尤推定法を利用し, 偏回帰 係数を教師ラベル付きの学習データから推定することによっ て行なわれる。

\section{$4.3 \mathrm{AIC}$ に基づいたデータ変数の選択}

実際にモデルを用いて判別を行なう場合には，統計モデル の過剩適合問題を考慮する必要がある。重回帰分析において は説明変数を増やすことによって予測精度が高まる傾向にあ る.しかし，説明変数を増やしすぎるとモデルが学習デー夕に 過剩に適合してしまい，未知のデー夕に対しては適合できず， モデルが汎化できていない状態となる。このような過剩適合 問題を避けるために，モデルの変数を適切に削減してモデル の簡略化を行なう必要がある。モデルで使用する説明変数の 選択を行なう際の指標の 1 つとして，赤池情報量基準 (AIC： Akaike Information Criteria) がある ${ }^{22)}$. AIC は複数のモ デルに対して相対的な比較を行なう際に利用される指標であ り，計算と解釈の容易さから使用されることの多い尺度であ る. AIC はモデル内のパラメータが最も少なく, 尤度が最大 となるモデルが最適であるという考え方のもとでモデルの比 較を行なっており，AICの值が小さいモデルほど良いモデル であるといえる。

変数の選択にはステップワイズ法を利用する．ステップワ イズ法は重回帰分析において変数選択を行なう際に一般的に 用いられる手法であり，AIC を始めとした基準值をもとにし て, 説明変数の取捨選択を行なう。モデルに最も有意な変数 を 1 つずつ追加していき，その都度モデルの AIC を計算して
Table 1 Worker's task for bumper assembly work

\begin{tabular}{c|c} 
No. & Task \\
\hline \hline task1 & Receive Bumper (Receive) \\
\hline task2 & Assemble Bumper (Assemble) \\
\hline task3 & Ready Tools (Ready) \\
\hline task4 & Tighten Bolts (Tighten) \\
\hline task5 & Return Tools (Return) \\
\hline task6 & Close Hatch (Close) \\
\hline task1' & Receive Bumper (Receive)
\end{tabular}

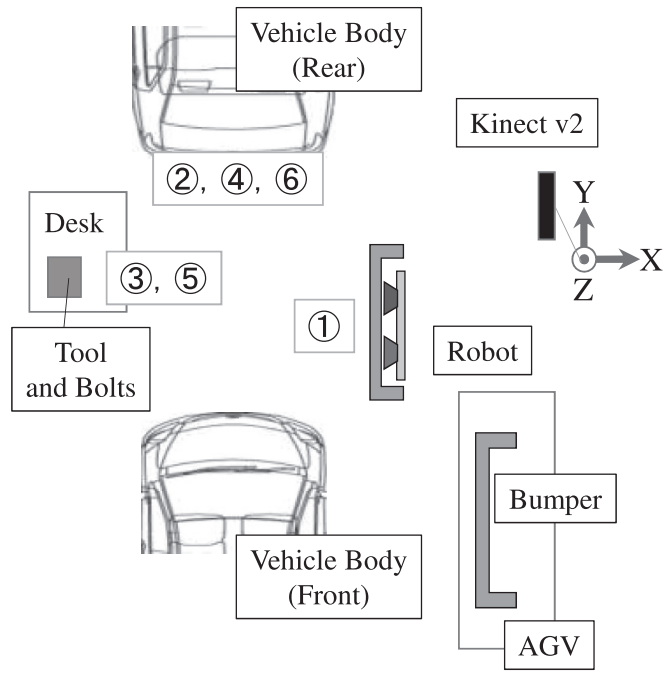

Fig. 3 Experimental environment

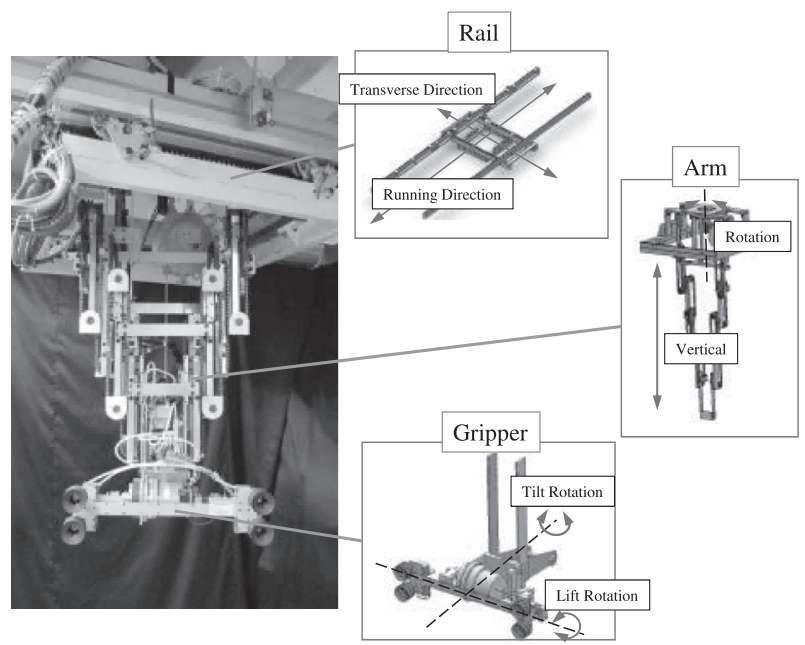

Fig. 4 B-PaDY

AIC の減少が止まった時点で変数の追加を終了する。これに より，部品供給直前の作業者の状態を説明するのに有意な変 数のみでモデルを構成し，モデルの汎化性能を向上させる.

\section{5. 実 験}

\section{1 実験条件}

本論文では, 実際のバンパ組付工程を模した環境でバンパの 供給実験を行ない，提案システムの有効性を検証する．Fig. 3 


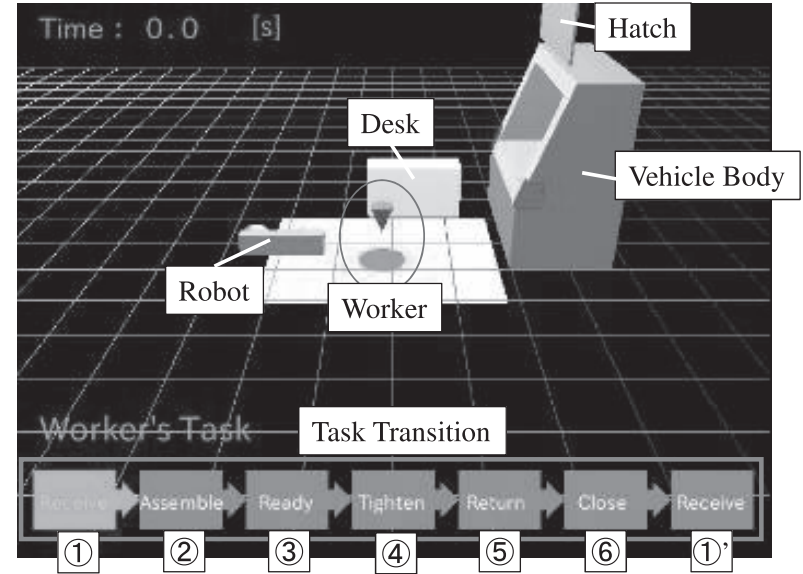

Fig. 5 Simulator for the bumper assembly work

に実験環境を示す．今回の実験では Fig. 3 上側の後部車体へ のバンパ組付けを行なう。Fig. 3 左側には作業机があり, バン パを固定するためのボルトと電動工具が置かれている. Fig. 3 中央部でロボットが動作し，ロボットは作業者へのバンパの 供給と AGV(Automatic Guided Vehicle, Fig. 3 右下) から のバンパの搬送を行なう．Fig. 3 右側に Kinect を設置してお り，前節で説明した各統計モデルの龙度計算を行なって，作 業内容の遷移の推定と供給夕イミングの決定を行なう.

Fig. 4 に，今回の実験に使用するパートナロボットである B-PaDY の試作機を示す. B-PaDY は水平方向の移動のた めの 2 自由度，把持部全体の回転と昇降のための 2 自由度, 把持したバンパのハンドリングを行なうための 2 自由度の計 6 自由度を有しており, 天吊り駆動式で動作することでバン パの搬送を行なう。バンパの把持には真空吸着式を採用して いる。バンパの裏側を 4 つの吸着パッドで吸着することによ り，バンパの形状に依存しない柔軟性と，把持を成功させる 確実性の向上を同時に実現している.

Fig. 3 図中の番号は Table 1 中の該当する作業が行なわ れる位置を表わしている。まず作業者はロボットからバンパ を受け取り (Receive), 後部車体のほうへ移動する。移動が 終わったら車体フレームにバンパを取り付ける (Assemble). その後は作業机から電動工具と 2 個のボルトを取り出して (Ready), 後部車体の 2 箇所のボルト締め付け作業を行なう (Tighten). ボルトの締め付けが終了したら電動工具を作業机 に戻し (Return), 最後に車体のハッチを閉める (Close).こ れで後部車体に対するバンパ組付作業が終了し，ロボットか らつぎに組付けるバンパを受け取る (Receive)。以上が今回 対象とするバンパ組付作業の手順である。

実験を行なうにあたって，事前実験として各統計モデルの 作成を行なった．各被験者の実験回数を 10 回として学習デー 夕を収集し，各被験者それぞれについてモデル作成を行なっ た。モデル作成後に，提案システムを用いて各被験者それぞ れ 10 回ずつバンパ供給実験を行ない，提案システムの評価 を行なう。学習データ収集時と実際の評価実験時の実験環境
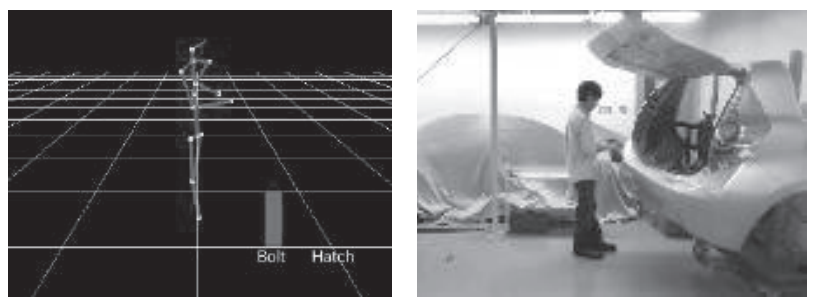

(a) Recognize the task of tightening the bolts
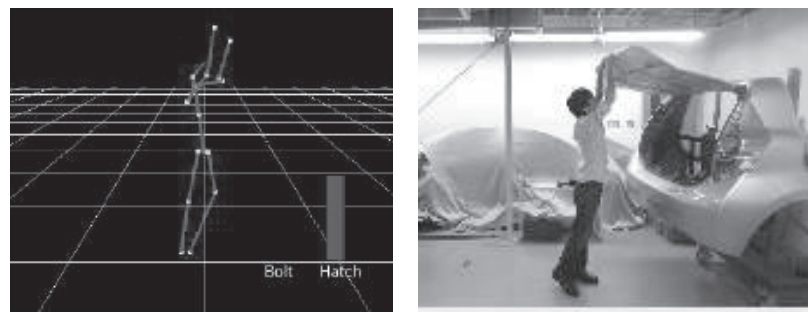

(b) Recognize the task of closing the hatch

Fig. 6 Recognize each task with HMM

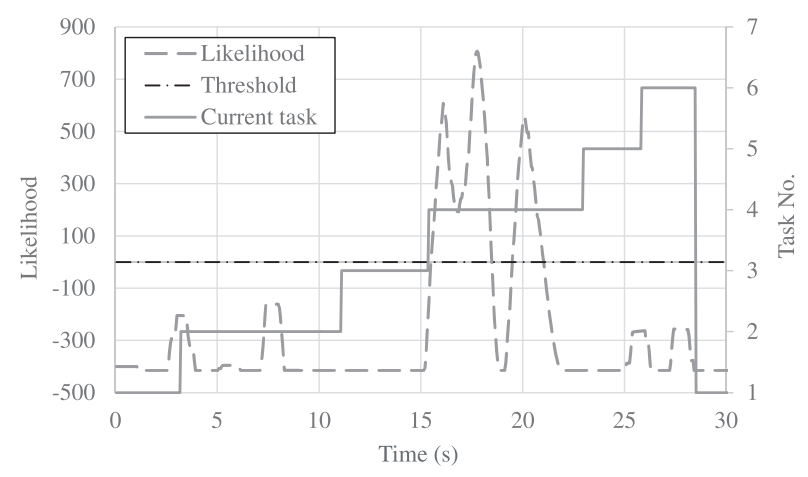

Fig. 7 Example of HMM likelihood for the task of tightening the bolts

は変わらないものとする.

Fig. 5 に，作業進度の推定結果を確認するために作成した シミュレータを示す。シミュレータの中央部のアイコンが作 業者を表わしており，その下のサークルの色が変化すること で GMM による作業位置情報を利用した作業領域判別の結果 を示す。また，シミュレータ下部のブロック線図は作業者の 作業の遷移を示しており，図中の番号が Table 1 中の対応す る作業を意味している。

\section{2 作業進度推定システムの評価}

提案する作業進度推定システムを利用して，実際に作業を 行なっている作業者のデータから作業進度を推定できるかど うかの検証を行なう。作業進度推定を行なうにあたって，本 実験で用いた作業遷移の判定方法をまとめると以下のとおり.

Receive $\Rightarrow$ Assemble

GMM による作業領域の推定

Assemble $\Rightarrow$ Ready

GMM による作業領域の推定

Ready $\Rightarrow$ Tighten

GMM による作業領域の推定と HMM による行動推定 Tighten $\Rightarrow$ Return 
Table 2 Summary of estimation performance

\begin{tabular}{c|c|c|c|c|c} 
Worker & $\begin{array}{l}\text { Estimation failure } \\
\text { (only GMM) }\end{array}$ & $\begin{array}{l}\text { Estimation failure } \\
(\mathrm{GMM}+\mathrm{HMM})\end{array}$ & $\begin{array}{l}\text { Tracking } \\
\text { failure }\end{array}$ & $\begin{array}{l}\text { Success rate } \\
\text { (only GMM) } \\
{[\%]}\end{array}$ & $\begin{array}{l}\text { Success rate } \\
\text { (GMM + HMM) } \\
{[\%]}\end{array}$ \\
\hline \hline SubjectA & 1 & 0 & 1 & 80 & 90 \\
\hline SubjectB & 1 & 1 & 2 & 70 & 70 \\
\hline SubjectC & 0 & 0 & 0 & 100 & 100 \\
\hline SubjectD & 8 & 0 & 0 & 20 & 100
\end{tabular}

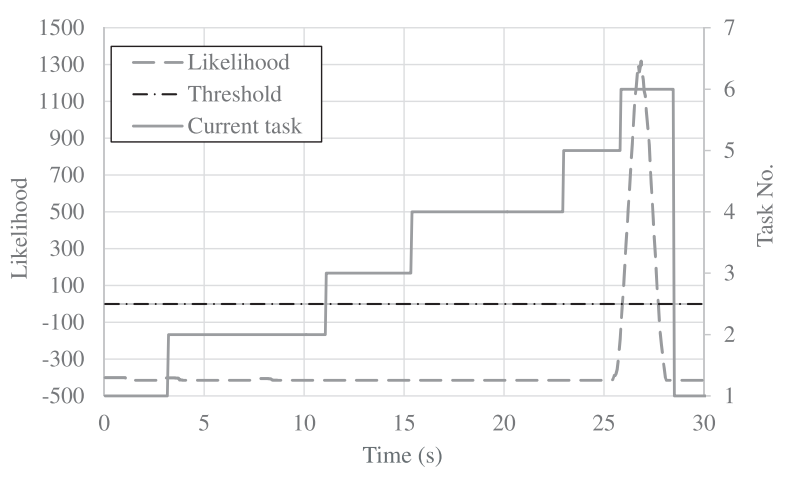

Fig. 8 Example of HMM likelihood for the task of closing the hatch

GMM による作業領域の推定

Return $\Rightarrow$ Close

GMM による作業領域の推定と HMM による行動推定

作業位置情報のみで遷移の判断可能な作業については, GMM による作業領域の推定結果から判断を行なう。車体傍で行な われる作業であるボルト締め付け作業 (Tighten) とハッチ閉 め作業 (Close) の 2 つについては，作業位置情報だけで推定 を行なうのは困難であるため，関節位置情報を利用した行動 推定を組み合わせることとする。

上述した方法でそれぞれの作業時の HMM を作成し，実 際に作業者の行動認識を行なっているようすを Fig. 6 に示 す。観測時系列の長さ $T$ は，各作業の作業時間を考慮して 20 フレーム分，つまり 1 秒間とした. HMM の状態数 $N$ は, Baum-Welch アルゴリズムが収束する最大の状態数とした結 果，今回の場合には $N=4$ となった．Fig. 6 左側の図は作業 者の関節位置の描画と，認識対象としている作業を行なって いる確率を表わす尤度のバープロットである。どちらの作業 についても，認識対象の作業を行なっているときに尤度の值 が上昇しており，作成した HMM によって作業者の行動を認 識できていることが確認できる。今回は対数尤度に対して閾 值を設けて判定を行ない，闇値は 0 と設定する。

Fig. 7 に, 実験を行なっている際のボルト締め付け作業判定 用の HMM による尤度計算の結果の一例を，Fig. 8 に，ハッ チ閉め作業判定用の HMM による尤度計算の結果の一例を示 す．各グラフの実線が，システムによって実際に判別された 作業の遷移を示し，破線が計算された尤度を示している。ど ちらの場合にも，対象とする作業が開始されたと判別してい
る時間に，HMM によって計算された尤度の值が大きく上昇 しており，一点鎖線で表わされる閾值を超えて作業が遷移し ていることが確認できる. Fig. 9 に，実験を行なっている際 のシミュレータと実世界のようすを示す．各作業を行なって いる間に，作業者の現在の作業をシステムが正しく推定して いるのが確認できる．提案手法を利用することによって，各 作業モデルによってすべての作業の遷移を確認してバンパの 供給が行なえることを確認した。

4 人の被験者が各 10 回ずつ行なった合計 40 回分の推定結 果を Table 2 に示す．比較対象として，作業者の作業位置 情報をもとにした GMM による推定のみで作業進度を推定し た場合の実験結果も示している。GMM のみで推定した場合 と比較して, GMM と HMM を組み合わせて推定を行なった 場合のほうが推定の成功率が高まっていることが確認できる. 作業位置のみを利用した場合，作業者によっては作業位置の ばらつきが大きく，工具机への移動とボルトの締め付け作業 の間に誤った作業遷移が発生してしまうケースが多く見られ た．作業者の関節位置情報を推定に利用することで，作業位 置のばらつきが大きい作業者についても精度よく作業進度が 推定できることが確認できた。

全被験者の結果を合計すると，Kinectの追跡失敗も含めた システム全体としての推定成功率は $90 \%$, 統計モデル自体の 推定成功率は $97.5 \%$ となった。推定の失敗原因は HMM によ るボルト締め付け作業の推定失敗であった。今回の実験失敗 の原因は, HMM による作業遷移の推定の失敗と, Kinect セ ンサによる作業者追跡の失敗の 2 つに大別される，HMMに よる作業遷移の推定の失敗については，入力変数やモデルパ ラメータの検討を行なって，モデルによる推定精度の向上を 図る必要があると考えられる. Kinectによる作業者の追跡の 失敗については，複数の Kinectをうまく統合させた計測シ ステムの構築，または Kinect 以外の新たなセンサの導入が 必要不可欠であると考えている.

\section{3 供給タイミング決定システムの評価}

前節において，実際の工程に近い複雑な作業フローに対し ても，供給タイミング決定システムが機能することを確認し た。本節では，バンパ供給夕イミングの決定について以下の 2 通りの方法で実験を行ない，提案システムの作業効率向上 への効果の検証を行なう.

Exp.1

作業者の位置を利用した供給夕イミングの決定

Exp.2 

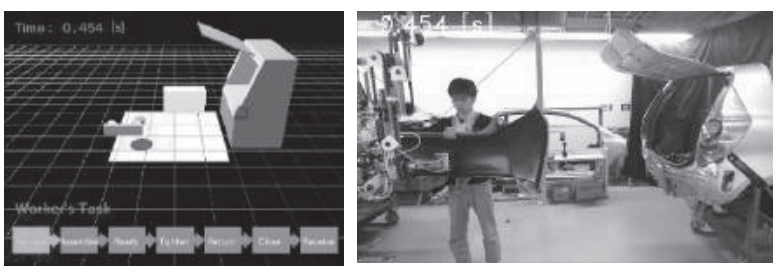

(a) Receive bumper (Time : $0.454 \mathrm{~s}$ )
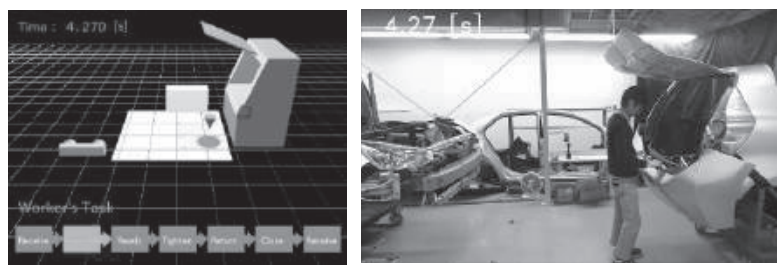

(b) Assemble bumper (Time : $4.270 \mathrm{~s}$ )
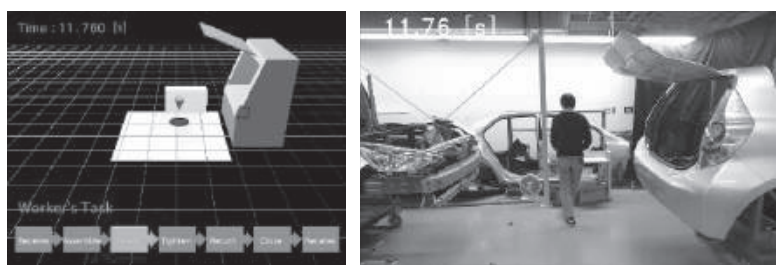

(c) Ready tools (Time : $11.760 \mathrm{~s}$ )
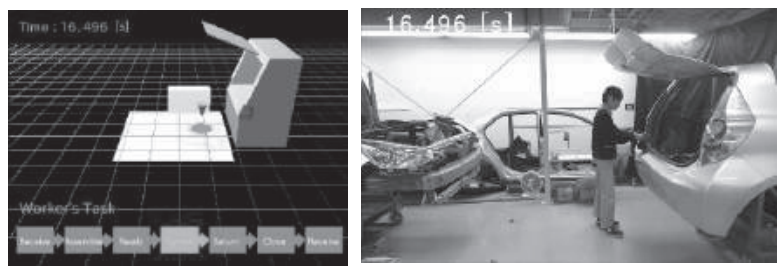

(d) Tighten bolts (Time : $16.496 \mathrm{~s}$ )
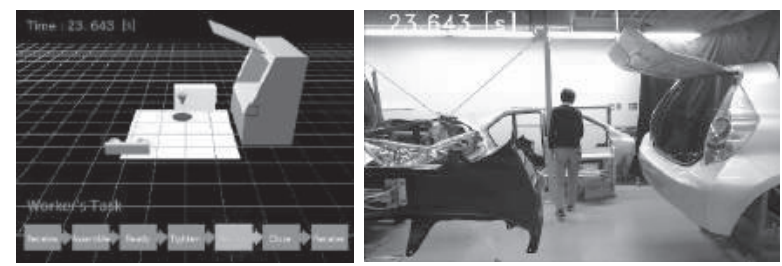

(e) Return tools (Time : $23.643 \mathrm{~s}$ )
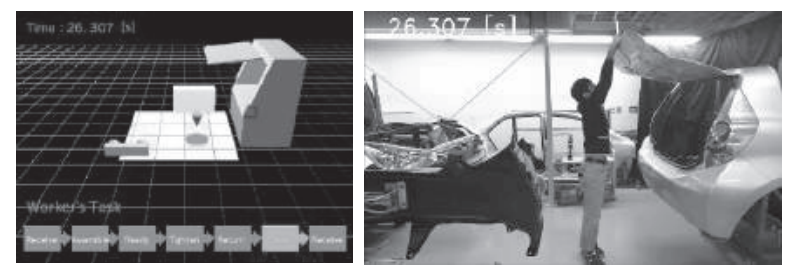

(f) Close hatch (Time : $26.307 \mathrm{~s}$ )
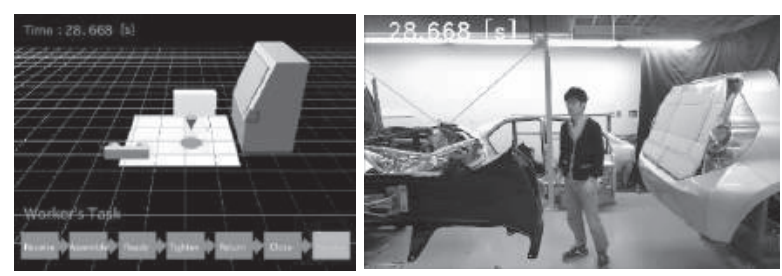

(g) Move to B-PaDY (Time : $28.668 \mathrm{~s}$ )
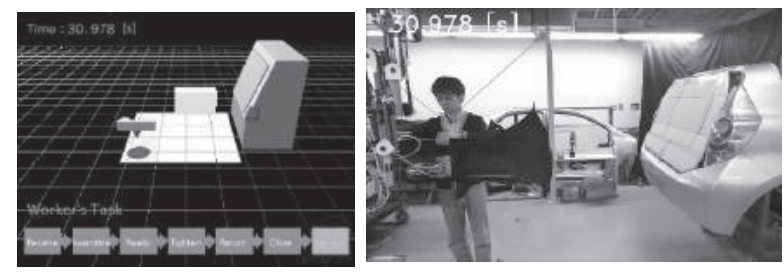

(h) Receive next bumper (Time : $30.978 \mathrm{~s}$ )

Fig. 9 Progress estimation results in each scene

ロジスティック回帰モデルを利用した供給タイミングの決定 Exp.1については, Handover Area に作業者が入ったと確認 した瞬間を供給開始タイミングとし，ロボットが供給運動を 開始する. Exp.2 については，ロジスティック回帰モデルに もとづいて供給タイミングの判断を行なう。今回対象とする バンパ組付工程における供給夕イミングは，ハッチを閉めた 後に作業者がバンパを受け取るために移動を開始した直前と する。実際に作成したモデルを利用して受け渡しタイミング を推定する際には，観測した説明变数から結果变数を決定す る必要がある。今回は閾值となる確率 $p_{T}$ を設定して以下の 式で計算する。

$$
y= \begin{cases}1, & p(y=1 \mid \boldsymbol{x}) \geq p_{T} \\ 0, & p(y=1 \mid \boldsymbol{x})<p_{T}\end{cases}
$$

今回は閾值確率を $p_{T}=0.9$ としている. また, センサの突 発的な外れ值による誤判断を避けるために, モデルの確率計 算結果が 3 フレーム以上連続して閾值確率 $p_{T}$ を超えていた 場合に供給を開始することとする，どちらの手法においても ロボットの動作時間は 2 秒間とし, あらかじめ決められた軌
道を動くものとする．

上記の 2 通りの供給タイミング決定手法について, 被験者 4 人に対して各 10 回，合計 80 回の実験を行なう.システムに よる作業進度の推定が失敗した場合には, 再度実験を行なっ ている. Fig. 10 に Exp.1，Exp.2 それぞれの実験における 各被験者供給待ち時間の平均と分散を示す。作業者が受け渡 し地点に到着したタイミングを，作業者が初めて Handover Area 内に存在し, かつ作業者の移動速度が $0.2 \mathrm{~m} / \mathrm{s}$ 以下に なったときと考え，ロボットと作業者の到着タイミングの差 の絶対值を供給待ち時間と定義している．作業者の供給地点 への到達が早すぎた場合，作業者がロボットからのバンパの 供給を待つ無䭾な時間が発生してしまう。一方で，ロボット の供給地点への到達が早すぎた場合, 工程を移動する作業者 の通行の妨害や商品である車体，バンパを傷つけてしまうリ スクが増加してしまう。このことから，作業者の到着に対し て，早すぎることも遅すぎることもないタイミングを適切で あると考える。全被験者について，ロジスティック回帰モデ ルによって供給タイミングを判断した場合のほうが，作業者 の待ち時間が削減されていることが確認できる，どの被験者 


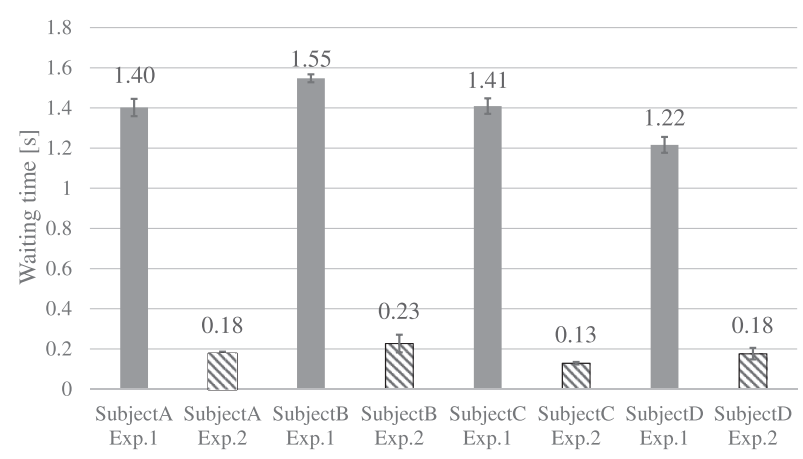

Fig. 10 Waiting time for each subject

についても，作業待ち時間が約 1 秒削減されており，今回提案 するシステムによって作業効率が向上していると考えられる.

しかし，特に被験者 B がロジスティック回帰モデルを利用 した場合において，各試行ごとの供給待ち時間の分散が大き くなっている。これは, 現在のシステムではロボットの供給 開始の夕イミングを決定しているだけであり，ロボットの移 動軌道については考慮されていないことが原因として考えら れる，そのため, 作業者の移動速度などによって, 各試行時の 供給時間にばらつきが生まれてしまっている。この供給時間 のばらつきが作業者への精神的な負荷につながると考えられ るため, ばらつきの少ない安定した供給の実現が課題となる.

\section{6. 結言}

本稿では, 従来の部品供給タイミング決定システムの成功 率を向上させるために，作業者が現在行なっている作業の進 度を GMM と HMM の組み合わせによって推定する手法を 提案した。提案した進度推定手法を従来システムに統合し， より複雑な作業工程においても提案システムが適用可能であ ることを確認した。ささらに，提案システムを用いて供給夕イ ミングを決定することで，作業者の供給待ち時間が低減でき ることを示した

今後の展望としては, 各作業モデルの学習アルゴリズムの オンライン化が挙げられる。本システムにおいては，すべて の作業モデルについて，事前に収集した学習デー夕をもとに してオフラインでモデルの学習が行なわれている。 そのため, 工程の変化や作業者の変化への対応が難しく, 毎回の作業モ デルの構築に時間をかけることを余儀なくされる．本システ ムにオンラインの学習アルゴリズムを導入することにより， 作業モデル構築のために要する労力が削減できるだけでなく, 作業者個人に合ったモデルの構築によって，作業進度推定精 度の向上も期待される。

また，実際の工程内での使用を想定したさらなるシステム の改良が挙げられる．実際の工程でロボットが人と同じ環境 下で作業を行なう場合には，作業者の安全の確保も重要な課 題となる. 本稿で提案した作業進度の推定は, 工程内の異常 の検出システムとしても応用可能なものであると考えている. 本稿では主に作業の効率化に焦点を当てていたが，効率化と
同時に安全も考慮に入れたシステム設計が今後の課題となる. また，本稿においてはバンパ組付工程を対象として作業モデ ルの作成と検証実験を行なったが，今後はそのほかの自動車 組立工程についても提案システムを実装して有効性を検証し ていく.

\section{参 考 文 献}

1) R. Wilcox, S. Nikolaidis and J. Shah: Optimization of Temporal Dynamics for Adaptive Human-Robot Interaction in Assembly Manufacturing, Robotics: Science and Systems, VIII, 441/449 (2013)

2) S. Nikolaidis, P. Lasota, G. Rossano, C. Martinez, T. Fuhlbrigge and J. Shah: Human-Robot Collaboration in Manufacturing: Quantitative Evaluation of Predictable, Convergent Joint Action, 44th International Symposium on IEEE Robotics (ISR), 1/6 (2013)

3) B. Mutlu, A. Terrell and C.M. Huang: Coordination Mechanisms in Human-Robot Collaboration, ACM/IEEE Intl. Conf. on Human-Robot Interaction (HRI)-Workshop on Collaborative Manipulation, 1/6 (2013)

4) J. Kinugawa, Y. Sugahara and K. Kosuge: Co-Worker Robot-PaDY, Acta Polytechnica Hungarica, 13-1, 209/221 (2016)

5）衣川, 金澤, 小菅：バンパ組付作業支援パートナロボット B$\mathrm{PaDY}$ 第 1 報：コンセプトと試作機の設計, 日本機械学会口 ボティクス・メカトロニクス講演会 2015，2P1-N07 (2015)

6）衣川, 久保田, 小菅：ドア組付作業支援パートナロボット DPaDY，計測自動制御学会論文集，52-3, 94/102 (2016)

7) Y. Tanaka, J. Kinugawa and K. Kosuge: Motion Planning with Worker's Trajectory Prediction for Assembly Task Partner Robot, 2012 IEEE/RSJ International Conference on IEEE Intelligent Robots and Systems (IROS), $1525 / 1532(2012)$

8）金澤，衣川，小菅：バンパ組付作業支援パートナロボット B$\mathrm{PaDY}$ 第 2 報：統計モデルによる作業支援タイミングの決 定，日本機械学会ロボティクス・メカトロニクス講演会 2015 , 2P1-L09 (2015)

9) A.P. Dempster, N.M. Laird and D.B. Rubin: Maximum Likelihood from Incomplete Data via the EM Algorithm, Journal of the Royal Statistical Society, Series B (methodological), 39-1, 1/38 (1977)

10) G. Schwarz: Estimating the Dimension of a Model, The Annals of Statistics, 6-2, 461/464 (1978)

11) M.D. Uddin, N.D. Thang and T.S. Kim: Human Activity Recognition via 3-D Joint Angle Features and Hidden Markov Models, 2010 17th IEEE International Conference on IEEE Image Processing (ICIP), 713/716 (2010)

12) L. Xia, C.C. Chen and J.K. Aggarwal: View Invariant Human Action Recognition Using Histograms of 3D Joints, 2012 IEEE Computer Society Conference on IEEE Computer Vision and Pattern Recognition Workshops (CVPRW), 20/27 (2012)

13) L.R. Rabiner: A Tutorial on Hidden Markov Models and Selected Applications in Speech Recognition, Proceedings of the IEEE, 257/286 (1989)

14) K.W. Strabala, M.K. Lee, A.D. Dragan, J.L. Forlizzi, S. Srinivasa, M. Cakmak and V. Micelli: Towards Seamless Human-Robot Handovers, Journal of Human-Robot Interaction, 2-1, 112/132 (2013)

15) P. Basili, M. Huber, T. Brandt, S. Hirche and S. Glasauer: Investigating Human-Human Approach and Hand-over, Human Centered Robot Systems, 151/160, Springer (2009)

16) M. Cakmak, S.S. Srinivasa, M.K. Lee, S. Kiesler and J. 
Forlizzi: Using Spatial and Temporal Contrast for Fluent Robot-Human Hand-overs, Proc. 6th International Conference on Human-robot Interaction (ACM), 489/496 (2011)

17) D.W. Hosmer, Jr. and S. Lemeshow: Applied Logistic Regression, John Wiley \& Sons (2004)

18) S.H. Lin, S.Y. Kung and L.J. Lin: Face Recognition/Detection by Probabilistic Decision-Based Neural Network, IEEE Transactions on Neural Networks, 8-1, 114/132 (1997)

19) J.P. Bigus: Data Mining with Neural Networks: Solving Business Problems from Application Development to Decision Support, McGraw-Hill (1996)

20) G. Madzarov, D. Gjorgjevikj and I. Chorbev: A Multiclass SVM Classifier Utilizing Binary Decision Tree, Informatica, 33-2, 233/241 (2009)

21) K.P. Bennett and J.A. Blue: A Support Vector Machine Approach to Decision Trees, The 1998 IEEE International Joint Conference on Neural Networks Proceedings, 3, 2396/2401 (1998)

22) H. Akaike: Information Theory and An Extension of The Maximum Likelihood Principle, Proceedings of the 2nd International Symposium on Information Theory, 267/281 (1973)

\section{[著 者 紹 介]}

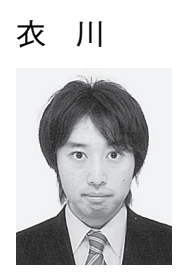

\section{潤}

2011 年東北大学大学院工学研究科バイオロボ ティクス専攻博士後期課程修了. 2011 年より同研 究科助教, 現在に至る. 組立作業支援パートナー ロボット，SDM を用いたロボットハンド，パワー アシストシステムに関する研究に従事. 日本機械 学会, 日本ロボット学会, IEEE などの会員. 博 士 (工学).

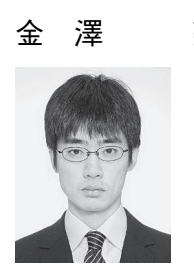

亮

2015 年東北大学工学部機械知能・航空工学科卒 業. 同年同大学博士前期 2 年の課程入学, 現在に 至る. 作業支援パートナロボットに関する研究に 従事.

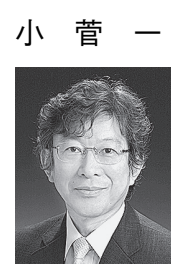

弘（正会員・フェロー）

1980 年東京工業大学大学院理工学研究科修士課 程修了. 同年日本電装 (現：デンソー) 入社. 82 年東京工業大学工学部助手. 90 年名古屋大学工学 部助教授を経て, 95 年東北大学工学部教授, 97 年 東北大学大学院工学研究科教授 (大学院重点化に よる配置換), 現在に至る. 工学博士. ロボット, メカトロニクス, マン・マシンシステム, 知能機 械などの研究に従事. IEEE Division X Director (2015 2016), IEEE Robotics and Automation Society President (2011 2012)。2002 年・2005 年日本機械学会賞 (論文). 2005 年日本ロボット 学会論文賞など受賞. IEEE Fellow，日本ロボッ 卜学会フェロー, 日本機械学会フェロー, 自動車 技術会フェロー。 